천연 암반 심해수 공급이 흰쥐의 면역반응 및 항산화 활성에

$$
\text { 미치는 영향 }
$$

정수진* · 주은정* · 유지영* · 김윤경* · 조용진** · 윤병선* · 조진국* · 남기택* · 황성구*

국립한경대학교 낙농과학과*, 진해개발(주)**

\title{
Effect of the Supply of Natural Water from Deep Sea Rock on the Immune Response and Antioxidant Activity in Rats
}

\author{
S. J. Jung*, E. J. Joo*, J. Y. Yoo*, Y. K. Kim*, Y. J. Cho**, B. S. Yoon*, \\ J. K. Cho*, K. T. Nam* and S. G. Hwang* \\ Dept. of Dairy Science, Hankyong National University*, Jinhaegaebal Co. Ltd.**
}

\begin{abstract}
This experiment was conducted to study the effects of the natural deep sea water, which contained approximately $2.3 \%$ salt, and various minerals of $\mathrm{K}, \mathrm{Mg}, \mathrm{Ca}, \mathrm{Na}, \mathrm{Fe}, \mathrm{Mn}, \mathrm{Zn}, \mathrm{Cu}$ etc, on the immune response and antioxidant activity in rats. 24 Sprague Dawley rats were randomly allotted to a control group and 3 treatment groups. Control rats were supplied with filtered tap water, and each treatment group rats were supplied with $0.5 \%$ deep sea water, $1 \%$ deep sea water and Jijangsoo, respectively, which is upper clear water separated from sediment by the clay. Feed and water were provided ad libitum throughout the experiment that lasted for 4 weeks. The results showed that $1 \%$ deep sea water group showed the highest values in weight gain, feed intake, and feed efficiency than those of other groups. The levels of water intake of $1 \%$ - and $0.5 \%$-deep sea water, and Jijangsoo group were $49.1 \%, 22.8 \%$, and $40.5 \%$ higher than that of control group, respectively. The Jijangsoo group rats showed that perirenal and epididymal adipose tissue weights were decreased by $32 \%$ and $25 \%(\mathrm{p}<0.05)$, respectively, when compared to control group rats. There were no remarkable differences of serum glucose concentration among all experimental groups. However, insulin concentration of experimental groups were remarkably increased in order of Jijangsoo (4.54), 1\% deep sea water (3.70), $0.5 \%$ deep sea water $(3.25)(\mathrm{p}<0.05)$. B cell and $\mathrm{T}$ cell stimulation were increased about $44.7 \%$ and $207 \%$, respectively, by $0.5 \%$ deep sea water in comparison with control $(\mathrm{p}<0.05)$. TBARS values of $0.5 \%$ deep sea water group were significantly lower than that of $\operatorname{control}(\mathrm{p}<0.05)$. Catalase and SOD activities of $0.5 \%$ deep sea water group were $200 \%$ and $47 \%$ higher than that of control, respectively. From the results, it can be concluded that the supply of natural deep sea water can slightly improve the physiological activity which modulates immune response and antioxidant activity in rats.
\end{abstract}

(Key words : Natural deep sea water, Immune response, Antioxidant activity, Lipid metabolism, Rat)

$$
\text { I. 서 론 }
$$

급속한 경제성장 위주의 산업사회 발달로 인 한 환경오염으로 이제 물도 직접 음용수로 이
용하기 어려운 문제를 안고 있어, 세계 각국에 서는 음용수로 이용하기 위하여 정수된 물과 미네랄이 보충된 기능성 물을 많이 찾고 있다. 여러 기능성 물중에 천연 암반 심해수(natural

Corresponding author: S. G. Hwang, Dept of Dairy Science, Hankyong National University, Seokjong-dong 67, Anseong-si, Kyonggi-do, 456-749, Korea. 
water from deep sea rock)는 암석의 미세한 틈 사이에 있는 물로 암반수가 형성되기까지는 1000년 이상이 걸리는데 움직이는 속도가 매우 느려 저수량이 매우 미비하다. 천연 암반 심해 수내에는 $\mathrm{Ca}, \mathrm{Mg}, \mathrm{Na}, \mathrm{K}, \mathrm{Fe}, \mathrm{HCO}_{3}, \mathrm{Cl}, \mathrm{SO}_{4}$, $\mathrm{NO}_{3}, \mathrm{SiO}_{2}$ 등 많은 광물질이 함유되어 있어, 최 근 외국에서는 천연 암반심해수 안에 함유되어 있는 많은 광물질을 이용한 연구가 활발히 진 행되고 있다(Miah, 1994).

특히, 암반 심해수는 Iron의 공급이 많아 생물 학적 이용도가 매우 높아(Worwood 등, 1996), 실제로 임신한 여성들의 철 부족으로 인한 빈혈 증에 암반 심해수의 철함유 황(Ferrous sulphate) 을 제공함으로서 빈혈을 피할 수 있는 철치료요 법(Iron therapy)이 제안되고 있다(Halkworth 등, 2003). 이렇게 다양한 광물질이 함유되어 있는 암반 심해수의 이용도를 고려해 볼 때 면역학 적인 면과 항산화 활성면에서도 효과가 있을 것으로 기대되는 바가 크다.

한편, 기능성이 있는 물로 동의보감에 기록된 지장수가 있는데 무근수(無根水)라고도 하며 황 토 땅속 깊이 흙을 파내어 숯으로 걸러낸 물과 황토를 알맞은 비율로 섞었을 때 생기는 윗물을 말한다. 옛날부터 해독작용이 있고 피를 맑게 해 주는 등의 약리효과가 있다고 하여 우리 선조들 이 애용하였으나, 과학적인 근거는 부족한 편이 나 웰빙바람을 타고 요즈음 기능성 식수로 이용 되고 있다. 이러한 식수들의 기능은 가축에 음수 로 사용하였을 때 궁극적으로 건강을 유지하는 데 효과가 있을 것으로 기대되며 그 이면에는 면역반응에도 어떠한 영향을 줄 것이 예상된다. 면역반응은 특정항원에 대하여 특이적으로 일 어나는데 이런 항원특이성 면역 반응 외에도 체 내에는 어떤 항원에 대해 노출된 경험이 없는 경우라도 대식세포와 같이 직접적으로 반응하 는 일종의 자연 면역반응이 있다(Sliverstein and Unkeless, 1991). 대식세포는 외부로부터의 자극 에 의해서 활성화되면 세포의 크기가 증가되고 여러 가지의 세포 분비물이 증가하게 되며, 탐식 능력과 종양세포 파괴 기능이 항진되어(Adams와 Hamilton, 1984), 외부로부터 들어오는 이 물질을 죽이거나 분해하여 제거하는 기능(phagocytosis)
을 가짐으로써 자연면역반응에 매우 중요한 기 능을 수행한다(Weir, 1986). 이러한 대식세포의 기능은 Interferon(IFN), lipopolysaccaharide(LPS) 등의 면역조절물질에 의해 활성화되어 암세포 에 독성이 있는 여러 가지 물질들을 분비하게 되며, 활성화된 대식세포에 의해 분비된 TNFa, IL-1, nitric oxide(NO)등은 암세포에 대한 세 포독성을 나타내는 물질로 제시되어져 왔다 (Hibbs 등, 1988 ; Thomas 와 Edginton, 1984). 이러한 면역반응에 암반심해수가 어떤 관계가 있는지를 규명하는 것은 가치 있는 일이라고 생각된다.

한편, 성인병의 $90 \%$ 는 불포화 지방산이 산화 하여 발생되는 과산화지질이 혈액순환계를 통 해 장애를 일으키면서 발생한다고 한다. 우리 인체에는 이러한 과산화지질을 제거하는 항산화 효소로서 Super oxide dismutase(SOD), Catalase, Glutathione-peroxidase가 존재하여 건강을 유지 할 수 있게 해 준다. 이러한 효소들은 성인이 되면서 효소들의 유도능(Induction capacity)이 저하되어 신체내의 과산화지질이 혈관벽 등에 침착되면서 서서히 성인병화 한다고 많은 의학 자들은 밝히고 있다(丹犲, 2002). 그러므로, 건 강을 유지하기 위해서는 면역력과 항산화활성 을 유지하는 것이 필요하며 각종 음식물을 섭 취하였을 때의 관련성을 규명하는 것은 영양학 적인 측면에서 매우 중요하다.

본 연구에서는 천연 암반 심해수가 면역반응 과 항산화 작용에 미치는 영향을 알아보기 위 하여 지장수와 함께 쥐에게 음용시키고 비장세 포내의 $\mathrm{B}$ 세포와 $\mathrm{T}$ 세포의 자극효과(Fusiwara, 1990)와 혈청내 콜레스테롤 성분 변화와 항산 화효소의 활성을 조사하였다.

\section{․ 재료 및 방법}

\section{1. 실험동물 사육}

실험동물은 Sprague Dawley종의 수컷 흰쥐 24 마리를 환경에 적응시키기 위하여 1 주일간 예비 사육 후 각 6마리 씩 무작위로 대조구와 3군의 처리구로 나누어 배치하였다. 대조구는 
정수(filtered tap water)를 급여하였고, 처리구 는 정수에 각각 $0.5 \%$ 암반심해수(영종도 앞바 다 해저 800 미터 암반으로부터 뽑아올린 물: (주)진해개발, 한국), $1 \%$ 암반심해수, 그리고 비 교를 위해 지장수(300 mesh 점토를 넣고 충분 히 혼합한 후 정치시켜 얻어진 상등수)를 급여 하였다. 4주간 실험사료와 물은 자유급식으로 섭취시키며 매일 물의 양을 체크하였다. 사육 실의 실내온도는 $25 \pm 2{ }^{\circ} \mathrm{C}$. 상대습도는 $60 \pm 5 \%$ 로 유지하였으며, 모든 실험군은 처치 24시간 전부터 물만 공급하고 금식시켰다. 일당 증체 량은 실험 종료시 체중을 사육마리수로 나누어 체중의 평균치를 구한 다음 이것을 사육일수로 나누어 구하였다. 식이 섭취량은 체중 측정 시 총 급여 사료량에서 잔여 사료를 감하여 구하 였고, 사료효율은 총 증체량을 총 사료섭취량 으로 나누어 계산하였다.

\section{2. 실험동물 처치 및 시료 수집}

동물 처치는 에테르로 마취시켜 개복한 즉시 복부대동맥으로부터 채혈하여 실온에서 30 분간 방치하여 응고되면 $1,000 \times \mathrm{g}$ 에서 10 분간 원심 분리하여 혈청을 얻었고 $-70^{\circ} \mathrm{C}$ 에 보관 후 분 석실험에 사용하였다. 장기는 채혈 직후 먼저 비장을 적출하였고 간은 빙냉의 $0.9 \%$ saline으 로 세척한 다음 적출하였다. 이어서 신장주위 지방과 정소상체지방을 적출하여 수분을 제거 한 후 무게를 측정하였다.

\section{3. 세포 성분의 분리}

실험동물을 마취한 후, 즉시 간을 절제하여 $0.9 \%$ saline용액으로 혈액을 씻어 내고 균질화한 다음, 이 균질물을 $1,000 \times \mathrm{g}$ 로 15 분 동안 원심분 리하고, 얻어진 상등액을 $20,000 \times \mathrm{g}$ 로 20 분 동안 원심분리 하여 얻어진 침전물을 mitochondria 분 획으로 사용하였다. 그 다음 상등액만을 100,000 $\times \mathrm{g}$ 로 60 분 동안 원심분리 하여 얻은 상등액을 세포질 분획으로 사용하였다. 각 분획은 -70 ${ }^{\circ} \mathrm{C}$ 에서 보관되었으며, 모든 실험은 $0 \sim 4{ }^{\circ} \mathrm{C}$ 에서 수행되었다.

\section{Alamar blue assay}

Rat을 해부용 가위로 하복부에서부터 흉부까 지 절개한 후 비장을 분리하고 RPMI-1640 media가 담긴 culture dish에 넣고 주사기 피스 톤 뒷부분을 이용하여 으깨고, 연결 조직 등이 혼입되지 않도록 혼합액을 피펫으로 조심스레 원심 튜브에 옮긴 후 $110 \times \mathrm{g}, 4^{\circ} \mathrm{C}$ 로 5 분간 원 심 분리하고 Vacuum pump로 상등액을 제거하 였다. 적혈구와 혼합되어 있는 펠렛의 적혈구 를 제거하기 위해 ACK buffer를 $1 \mathrm{ml}$ 넣고 잘 혼합, 약 1 분간 정치 후 $110 \times \mathrm{g}, 5 \mathrm{~min}, 4^{\circ} \mathrm{C}$ 로 원심분리 하고 RPMI 1640 media를 넣어 응축 되어 있는 세포가 잘 떨어지도록 혼합하였다. 세포수를 계수하여 spleen cell을 96well에 $5 \times$ $10^{5} \mathrm{cells} / \mathrm{ml}$ 로 200ul 분주한 후 LPS와 Con A를 첨가하여, $\mathrm{CO}_{2}$ incubator에서 24시간 배양하고 alamar blue $20 \mu$ e 처리한 다음 각각 24시간과 48시간대에 나타난 $570 \mathrm{~nm}$ 의 흡광도(reference $600 \mathrm{~nm}$ )를 ELISA reader로 측정하여 $\mathrm{B}, \mathrm{T}$ cell 등의 면역세포 활성을 확인하였다.

\section{TBARS(Thiobarbituric acid reactive sub- stances) 측정}

malondialdehyde(MDA)량을 2-thiobarbituric acid (TBA)로 비색 정량하는 Buege와 Aust방법(1978) 을 이용하였다. 즉 간조직을 가용화한 시료에 $\mathrm{TBA}$ 시약 $2 \mathrm{ml}$ 을 첨가한 후, 15 분간 $100^{\circ} \mathrm{C}$ water bath에서 중탕 시키고 실온에서 냉각시킨 다음, $1000 \times \mathrm{g}$ 로 10 분간 원심분리 하여 얻어진 상층 액의 흡광도를 $535 \mathrm{~nm}$ 에서 측정하였다.

\section{6. $\mathrm{SOD}($ Superoxide dismutase)의 활성도 측정}

SOD assay는 Kuthan 등(1986)의 방법을 기초 로 한 SOD Assay kit-WST(Dojindo, JAPAN)를 이용하여 실시하였다.

\section{Catalase 측정}

$5 \mathrm{mM}$ EDTA 첨가된 $1 \mathrm{M}$ Tris- $\mathrm{HCl}$ 완충액 $(\mathrm{pH}$ 
8.0)에 기질로 $10 \mathrm{mM} \mathrm{H} \mathrm{H}_{2}$ 용액을 첨가하여 37 ${ }^{\circ} \mathrm{C}$ 에서 10 분간 incubation 시킨 후, 시료액을 취 하여 cuvette에 넣고 $240 \mathrm{~nm}$ 에서 1 분 동안 흡광 도의 변화를 측정하였다.

\section{8. 혈청 분석}

혈청 분석은 자동 혈액 분석기(Olympus AV $640, \mathrm{JAPAN}$ )를 이용해 triglyceride(TG), free fatty acid, HDL-cholesterol, LDL-cholesterol, insulin, glucose를 측정하였다.

\section{9. 통계처리}

시험 결과에 대한 통계분석은 SAS package (1996)의 분산분석 및 일반 선형모델(GLM)을 이용하였고, 각 처리구별 유의성 검증은 Duncan's multiple range test(Duncan, 1955)에 의하여 분석 하였다.

\section{III. 결과 및 고찰}

\section{1. 사양실험 결과}

(1) 증체량, 사료섭취량 및 사료효율

실험기간 중 흰쥐에게 암반심해수 및 지장수 를 급여한 후의 조사된 평균 증체량, 사료섭취 량 및 사료효율은 Table 1과 같다. 증체량은 $1 \%$ 의 암반수의 경우가 대조군보다 약 $7 \%$ 가량 높은 증체량을 보였다. $0.5 \%$ 암반심해수와 지 장수의 경우는 대조군과 비슷한 수준의 증체량
을 보였다. 사료섭취량은 처리구간에 큰 차이 는 없었으나 $1 \%$ 의 암반심해수 처리군의 경우 가 대조군보다 유의하게 높은 것으로 나타났다 $(\mathrm{p}<0.05)$. 사료효율은 유의차는 없었으나 $0.5 \%$ 암반심해수 처리군이 대조군보다 약간 낮은 것 을 제외하고는 지장수 및 $1 \%$ 의 암반심해수의 경우 높아지는 경향을 나타냈다. 전체적으로 $1 \%$ 의 암반수의 경우가 증체량 및 사료섭취량, 사료효율이 우수한 것으로 나타났다.

반면에 총음수량은 모든 처리군이 대조군 보 다 많은 음수량을 보였는데, $0.5 \%$ 암반심해수 의 경우는 $49 \%, 1 \%$ 암반심해수는 $22.8 \%$, 지장 수는 $40.5 \%$ 가량 더 많은 것으로 나타났다 $(\mathrm{p}<0.05)$. 전체적으로 처리군의 총음수량이 대 조군보다 유의하게 많은 것으로 나타나, 기호 성이 양호한 것으로 판단되었다.

(2) 각 조직무게

Table 2는 각 조직의 무게를 조사한 결과이 다. 각 조직무게의 경우, 대조군과 비교하여 $0.5 \%$ 나 $1 \%$ 암반심해수군 및 지장수군 모두에 서 별다른 차이를 보이지 않았다. 그러나 지장 수를 급여한 군의 신장주위지방은 유의하게 감 소한 것으로 나타났으며 $(\mathrm{p}<0.05)$, 정소상체지방 무게의 경우 유의차는 없었으나 정소주위지방 의 결과와 같이 감소하는 경향을 나타내었다. 이 결과로부터 $0.5 \%$ 또는 $1 \%$ 의 암반심해수 공 급은 대조군과 비교하여 간 조직, 신장주위 및 정소상체 지방무게에는 차이가 없는 결과로부 터 영양소이용성에는 영향을 미치지 않는 것으 로 사료되었다. 그러나 지장수 공급군의 경우

Table 1. Body weight gain, feed intake, feed efficiency and water intake in rats fed three experimental water

\begin{tabular}{|c|c|c|c|c|}
\hline \multirow{3}{*}{ Items } & \multicolumn{4}{|c|}{ Groups } \\
\hline & \multirow{2}{*}{ Control } & \multicolumn{2}{|c|}{ Deep sea water } & \multirow{2}{*}{ Jijangsoo } \\
\hline & & $0.5 \%$ & $1 \%$ & \\
\hline Body weight gain (g/day) & $139.3 \pm 6.94$ & $140.7 \pm 15.21$ & $150.5 \pm 3.51$ & $145.7 \pm 14.77$ \\
\hline Feed intake (g/day) & $506.0 \pm 4.61^{\mathrm{b}}$ & $518.0 \pm 10.75^{\mathrm{ab}}$ & $532.0 \pm 18.07^{\mathrm{a}}$ & $508.0 \pm 11.56^{b}$ \\
\hline Feed efficiency ${ }^{1)}$ & $0.28 \pm 0.01$ & $0.27 \pm 0.02$ & $0.28 \pm 0.01$ & $0.29 \pm \quad 0.03$ \\
\hline Water intake (ml/day) & $1066.8 \pm 6.63^{\mathrm{c}}$ & $1816.1 \pm 71.85^{\mathrm{a}}$ & $1471.4 \pm 44.88^{\mathrm{b}}$ & $1763.0 \pm 235.97^{\mathrm{a}}$ \\
\hline
\end{tabular}


Jung et al. ; Effect of Natural Water from Deep Sea Rock on the Immune Response and Antioxidant Activity in Rats

Table 2. Liver weights and adipose tissues in rats fed the each experimental water

(Unit: g)

\begin{tabular}{lcccl}
\hline Organs & Control & $0.5 \%$ deep sea water & 1\% deep sea water & Jijangsoo \\
\hline \hline Liver & $8.5 \pm 0.41$ & $8.5 \pm 1.03$ & $9.1 \pm 1.81$ & $9.5 \pm 0.59$ \\
PAT $^{1)}$ & $5.5 \pm 0.80^{\mathrm{a}}$ & $5.1 \pm 0.86^{\mathrm{ab}}$ & $5.2 \pm 1.02^{\mathrm{ab}}$ & $3.7 \pm 0.78^{\mathrm{b}}$ \\
EAT $^{2)}$ & $4.3 \pm 1.21$ & $4.2 \pm 0.45$ & $4.1 \pm 0.86$ & $3.2 \pm 0.63$ \\
\hline
\end{tabular}

1) PAT : Perirenal adipose tissue. ${ }^{2)}$ EAT : Epididymal adipose tissue.

ab Values with different superscripts are significantly different $(\mathrm{p}<0.05)$.

정소상체지방 및 신장주위지방이 유의하게 감 소하는 것으로 나타나 지방생합성 및 지방분해 효소활성을 측정하지 않아 정확한 원인은 알 수 없으나 사료효율에서는 대조군과 비교해 차 이가 없는 것으로 나타나 지방생합성을 위한 에너지 재분배는 줄고 체단백질 합성을 증가시 켰을 가능성이 시사되어 앞으로 더욱 연구가 필요하다고 판단되었다.

(3) 비장세포 자극능

비장세포의 자극능을 조사한 결과를 Fig. 1에 나타내었다. B cell의 분열을 자극하는 mitogen 인 LPS를 처리하였을 때 $0.5 \%$ 암반심해수를 급 여한 rat의 비장세포는 대조군보다 $44.7 \%, 1 \%$ 암반심해수를 급여한 군은 $26 \%$ 의 높은 증식능 을 보였으며, 지장수군은 $62 \%$ 의 유의적으로 높 은 증식능을 보였다 $(\mathrm{p}<0.05)$. 또한 $\mathrm{T}$ cell의 분 열을 자극하는 mitogen인 Con A를 각각의 비장

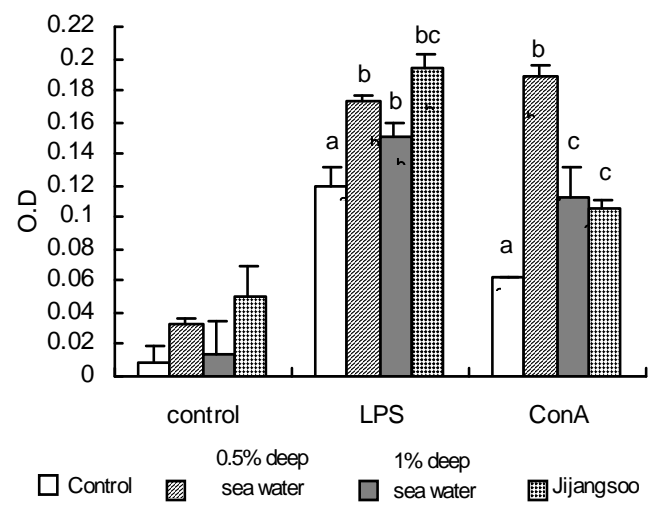

Fig. 1. Mitogenic activity of spleen cells in rats fed with deep sea water and Jijangsoo.

Values are mean \pm SD.

abc Values with different letter are significantly different $(p<0.05)$
세포에 처리한 결과, $0.5 \%$ 암반심해수를 급여 한 군에서는 $207 \%, 1 \%$ 암반수를 급여한 군에 서는 대조군보다 유의적으로 $82 \%$ 높은 증식능 을 보였으며, 지장수도 $71 \%$ 높은 증식능을 보였 다 $(\mathrm{p}<0.05)$. 암반수를 적용할 때는 면역증강에 대한 효과가 농도에 비례하기보다는 적당한 량 을 사용하는 것이 바람직한 것으로 사료되었다. 유방암 환자나 위절제 암환자에 있어서 mineral water의 음용이 B, T cell을 유의성 있게 증가시 킨 결과(Vladimirov 등, 2004)처럼, 전체적으로 암반심해수나 지장수를 급여하였을 때 $\mathrm{B}, \mathrm{T}$ cell 등의 면역세포가 활성화되는 것이 시사되었다.

이러한 결과는 mineral water를 사람이 음용하였 을 때, glucocorticoids를 높여 면역증강효과를 준 결과나(Kolesnikov 등, 2002), rat에게 급여하였을 때 항체형성세포가 $95.86 \%$ 증가하고 phagocytosis 활성이 증가하였다는 보고(Dolgushin 등, 2000) 처럼 암반심해수 중의 미네랄 성분이 체액성 또 는 세포성 면역체계에 긍정적인 면역증강효과를 주는 것으로 사료되었다.

(4) 혈청 분석

\section{1) 지질성분 분석}

혈청 내 지질성분을 분석한 결과는 Table 3 에 나타냈다. Triglyceride를 측정한 결과 유의 성은 없으나 지장수의 경우는 $10 \%$ 의 감소, $0.5 \%$ 암반심해수의 경우는 $4 \%$ 의 감소효과를 보였다. 그러나 $1 \%$ 암반심해수의 경우는 오히려 증가하 는 결과를 보였다. Free fatty acid는 대조군에 비 해 지장수와 $1 \%$ 암반심해수 처리군에서는 차이 가 없었으나 $0.5 \%$ 암반심해수의 경우는 $4.2 \%$ 정도 감소된 결과가 나타났다. 혈청 중 free fatty acid는 총지방산의 4 5\%에 지나지 않으나 주 
로 albumin과 결합하여 존재하며 말초조직의 중요한 에너지원으로 감소될 경우 비만이 개선 되는 것으로 알려져 있다(최 등, 2002). 또, 혈청 내 총콜레스테롤 수치를 조사한 결과 암반심해 수 및 지장수가 대조군에 비해 유의성은 없으 나 약간 증가되는 경향을 보여, 총콜레스테롤 수치를 감소시키는 데는 효과가 없음을 알 수 있었다. HDL-cholesterol은 대조군 및 처리군 모 두 정상범위에 해당하는 수치이나 지장수의 경 우는 $6 \%, 0.5 \%$ 암반심해수의 경우는 $11.1 \%$, $1 \%$ 암반심해수의 경우는 $7.2 \%$ 정도 증가하는 결과를 나타냈다. HDL-cholesterol이 증가되는 경우 비만이 감소하고 동맥경화 발생율이 감소 하는 것으로 알려져 있으므로(Steneberg 등, 2005), 이 결과는 긍정적인 것으로 생각된다. LDL-cholesterol는 지장수군은 대조군과 거의 비 슷하게 나타났으나 $0.5 \%$ 및 $1 \%$ 암반심해수 처 리군은 유의성은 없으나 약 $45.9 \%$ 및 $34.3 \%$ 정 도 감소하는 것으로 나타났다. $0.5 \%$ 암반심해 수의 급여는 혈청내 기타의 지질성분은 대조군과 별 차이가 없었으나 HDL-cholesterol이 약간 증가 되고 Triglyceride, Free fatty acid, LDL-cholesterol 이 크게 감소되어 동맥경화 등 혈관질병의 예방 에 약간은 도움이 될 것으로 사료된다.
2) Glucose, Insulin, TBARS 및 항산화 효소 활성 분석

혈청 내 glucose농도는 통계적인 유의차는 나 타나지 않았지만 처리군 모두 대조군보다 증가 되는 경향을 보였다(Table 4).

혈청내 인슐린의 농도는 처리군 모두가 대조군 보다 증가하여 지장수, $1 \%$ 암반심해수, $0.5 \%$ 암반 심해수 순으로 현저하게 높게 나타났다( $\mathrm{p}<0.05)$. 이 결과로부터 지장수 및 암반심해수의 음용이 인슐 린의 농도를 높여 당뇨병의 개선에 도움이 될 것 으로 사료되었다. 인슐린은 혈당농도를 낮추어 주 는 것 외에 지방합성을 증가시키고 간장과 지방조 직에서 지방 가수분해를 억제하여 지방축적을 일 으킨다. 본 연구 결과, glucose농도의 상승이 insulin 의 분비를 상승시켰을 가능성이 있을 것으로 고찰 되나, Table 2의 정소상체지방 및 신장 지방조직의 무게에 유의한 차이가 없는 것을 고려해 볼 때 심 해수 급여에 의한 glucose 흡수 뿐 만 아니라 지방 분해도 촉진되었을 가능성도 사료되었다.

TBARS는 유지나 유지식품에 있어 산화시 생성되는 carbonyl화합물 중 malondialdehyde의 량을 나타내는 수치로서 유지의 산패도나 항산 화활성을 측정하는 척도이다. 혈청 내의 TBARS 의 양은 $0.5 \%$ 암반심해수는 $21.8 \%, 1 \%$ 암반심

Table 3. Biochemical values of serum lipid compositions in each experimental group rats.

\begin{tabular}{|c|c|c|c|c|c|}
\hline Group & $\begin{array}{l}\text { Triglyceride } \\
\text { (mg/dl) }\end{array}$ & $\begin{array}{l}\text { Free fatty acid } \\
\quad(u E q / L)\end{array}$ & $\begin{array}{c}\text { Total } \\
\text { cholesterol } \\
\text { (mg/dl) }\end{array}$ & $\begin{array}{l}{ }^{1)} \mathrm{HDL} \\
\text {-cholesterol } \\
\text { (mg/dl) }\end{array}$ & $\begin{array}{l}{ }^{2)} \text { LDL } \\
\text {-cholesterol } \\
\text { (mg/dl) }\end{array}$ \\
\hline Control & $69.2 \pm 11.55$ & $1143.8 \pm 129.64$ & $45.7 \pm 2.86$ & $45.7 \pm 2.86$ & $179.2 \pm 82.61$ \\
\hline $0.5 \%$ deep sea water & $66.5 \pm 26.62$ & $1097.3 \pm 156.43$ & $53.0 \pm 5.02$ & $50.8 \pm 5.44$ & $97.0 \pm 19.85$ \\
\hline $1.0 \%$ deep sea water & $83.8 \pm 27.80$ & $1153.5 \pm 316.76$ & $50.3 \pm 4.89$ & $49.0 \pm 4.90$ & $117.7 \pm 58.45$ \\
\hline Jijangsoo & $62.8 \pm 15.62$ & $1182.2 \pm 173.46$ & $49.5 \pm 1.95$ & $48.7 \pm 2.08$ & $160.0 \pm 30.10$ \\
\hline
\end{tabular}

${ }^{1)}$ HDL-cholesterol: High density lipoprotein. ${ }^{2)}$ LDL-cholesterol: Low density lipoprotein.

Values are mean \pm SD

Table 4. Serum glucose, Insulin levels and antioxidant activities of liver in each group rats.

\begin{tabular}{lcccccc}
\hline Group & $\begin{array}{c}\text { Glucose } \\
(\mathrm{mg} / \mathrm{ml})\end{array}$ & $\begin{array}{c}\text { Insulin } \\
(\mu \mathrm{IU} / \mathrm{ml})\end{array}$ & $\begin{array}{c}\text { TBARS } \\
(\mathrm{nmol} / \mathrm{ml})\end{array}$ & $\begin{array}{c}\text { Catalase } \\
(\mathrm{Unit} / \mathrm{ml})\end{array}$ & $\begin{array}{c}\mathrm{Cu} / \mathrm{Zn} \mathrm{SOD} \\
(\%)\end{array}$ & $\begin{array}{c}\text { Mn SOD } \\
(\%)\end{array}$ \\
\hline \hline Control & $165.7 \pm 7.94$ & $1.0 \pm 0.44^{\mathrm{a}}$ & $6.1 \pm 0.87$ & $0.4 \pm 0.12$ & $33.8 \pm 5.45$ & $65.2 \pm 2.03$ \\
$0.5 \%$ deep sea water & $174.50 \pm 11.02$ & $3.3 \pm 0.74^{\mathrm{ab}}$ & $5.1 \pm 0.65$ & $1.4 \pm 0.32$ & $50.0 \pm 7.01$ & $66.5 \pm 5.79$ \\
$1.0 \%$ deep sea water & $182.8 \pm 25.65$ & $3.7 \pm 0.38^{\mathrm{ab}}$ & $4.5 \pm 0.77$ & $0.3 \pm 0.14$ & $57.7 \pm 4.88$ & $68.9 \pm 3.53$ \\
Jijangsoo & $174.0 \pm 11.02$ & $4.5 \pm 0.80^{\mathrm{b}}$ & $5.1 \pm 0.76$ & $0.6 \pm 0.11$ & $40.7 \pm 4.38$ & $71.0 \pm 4.19$ \\
\hline
\end{tabular}

Values are mean \pm SD

${ }^{\mathrm{ab}}$ Values with different superscripts are significantly different $(\mathrm{p}<0.05)$. 
해수는 $34.7 \%$, 지장수는 $20.8 \%$ 정도 감소하여, 처리군 모두에서 과산화지질의 생성을 억제하는 효과가 있는 것으로 나타났다(Table 4). Catalase 는 과산화수소를 제거하는 세포 방어 제2항산화 제로서 과산화지질을 중화 내지 분해하는 특성 이 있는데, 이 효소활성은 대조군보다 특히 $0.5 \%$ 암반심해수의 경우 $294 \%$, 지장수는 $63 \%$ 가 증가 하여 간접적인 항산화 작용이 있을 것으로 생각 된다. 또, $\mathrm{Cu} / \mathrm{Zn} \mathrm{SOD}$ 의 활성은 주로 세포질과 핵내에서 작용하는 제 1 항산화제로서 대조군에 비해 처리군이 모두 증가한 경향을 보였으며, 지 장수의 경우는 $20.4 \%, 0.5 \%$ 암반심해수의 경우 는 $47.9 \%, 1 \%$ 암반심해수의 경우는 $70.7 \%$ 증가 하여 간접적인 항산화 효과가 예상된다. 또, $\mathrm{Mn}$ $\mathrm{SOD}$ 활성은 주로 미토콘드리아 내에 존재하는 제 1 항산화제로서 대조군에 비하여 유의한 차이 는 보이지 않았으나 지장수의 경우가 $8.8 \%$ 정도 증가한 결과를 보였으며 다른 처리군들도 대조 군에 비하여 약간 높은 효소활성을 나타냈다. 결과적으로 천연 암반심해수가 흰쥐의 면역 활 성 및 항산화 활성, 지질 대사를 조절하는 긍정 적인 생리적 활성이 있는 것으로 사료되었다.

많은 의학자들은 과산화지질이 혈액순환계에 장애를 일으키고 $\mathrm{LDL}$ 콜레스테롤이 혈관벽 등 에 침착되면 서서히 성인병화 한다고 밝히고 있는데(Wood 등, 1983), 암반심해수를 급여할 경우 과산화지질을 제거하는 $\mathrm{SOD}$, Catalase 효 소가 신체내의 과산화지질이 혈관벽 등에 침착 되는 것을 막아 줌으로써 건강을 유지하도록 해 줄 가능성이 있을 것으로 사료된다.

본 연구결과를 종합하여 볼 때, 가축에 천연 암반심해수의 급여는 LDL 콜레스테롤의 농도 가 유의적인 차이는 없지만 감소되었고, 면역 활성 및 항산화효소의 활성은 상대적으로 높아 져 활성산소에 의한 노화방지와 동맥경화 예방 등에도 효과가 있을 것으로 사료되었다.

\section{IV. 요 약}

본 연구에서는 천연 암반심해수를 가축 음용 수로 개발하고자 $2.3 \%$ 염분을 함유하고, 칼륨 $(\mathrm{K})$, 마그네슘 $(\mathrm{Mg})$, 칼슘 $(\mathrm{Ca})$, 나트륨 $(\mathrm{Na})$, 철 $(\mathrm{Fe})$,
망간(Mn), 아연(Zn), 구리(Cu) 등의 광물질을 함 유한 암반심해수를 $0.5 \%$ 및 $1 \%$ 로 희석하여 흰 쥐에 공급하며 면역 반응과 항산화 활성에 미 치는 영향을 조사하였다. 공시동물로 Sprague Dawley종의 수컷 흰쥐 24마리를 6마리 씩 대조 군과 3 개의 처리군으로 임의 배치하고, 대조군 은 정제수를 급여하였고 처리군은 각각 $0.5 \%$ 암반심해수, $1 \%$ 암반심해수, 지장수를 공급하 여 4 주 동안 사육하였다. 실험 결과, $1 \%$ 의 암 반수의 경우가 증체량 및 사료섭취량, 사료효 율이 우수한 것으로 나타났다. 총음수량은 대 조군 보다 $0.5 \%$ 암반심해수의 경우는 $49 \%, 1 \%$ 암반심해수는 $22.8 \%$, 지장수는 $40.5 \%$ 가량 더 많은 것으로 나타났다 $(\mathrm{p}<0.05)$. 각 조직무게의 경우, 지장수군의 신장주위지방과 정소상체지 방은 각각 $32 \%, 25 \%$ 적은 것으로 나타났다 $(\mathrm{p}<0.05) . \mathrm{B}$ 세포와 $\mathrm{T}$ 세포 자극능은 처리군중에 서 $0.5 \%$ 암반심해수 급여군이 가장 높아 대조군 보다 $44.7 \%$ 와 $207 \%$ 증가한 것으로 나타났다 $(\mathrm{p}<0.05)$. 또 $0.5 \%$ 암반심해수가 혈청 내 triglyceride는 $4 \%$, Free fatty acid는 4\%, LDL- cholesterol은 45.9\% 감소시키는 등 지질성분 변화에 가장 긍정적인 효과를 나타내었다. 항산화 활성의 경우 TBARS 의 양은 $0.5 \%$ 암반심해수는 $21.8 \%, 1 \%$ 암반심 해수는 $34.7 \%$, 지장수는 $20.8 \%$ 정도 감소하였 다. catalase 활성은 $0.5 \%$ 암반심해수가 약 2.9 배, 지장수가 약 1.6 배 증가하였으며, $\mathrm{Cu} / \mathrm{Zn} \mathrm{SOD}$ 활 성은 $0.5 \%$ 암반심해수,가 약 1.5 배, $1 \%$ 암반심 해수가 약 1.7 배, 지장수가 약 1.2 배 증가하였으 며, $\mathrm{MnSOD}$ 활성은 모든 처리군이 대조군에 비 해 약간 증가하였다.

이상의 결과로부터 가축에 $0.5 \%$ 암반심해수의 급여는 $\mathrm{LDL}$ 콜레스테롤의 농도가 감소되고, 면역 활성 및 항산화효소 활성이 높아지는 등 고급 축 산물생산의 음용수로 유익할 것으로 고찰되었다.

$$
\mathrm{V} \text {. 사 사 }
$$

본 연구는 2004, 2005년도 경기도 고품질친 환경농축산물생산기술연구센터(GRRC)와 (주)진 해개발의 지원을 받아서 수행된 과제로서 지원 에 감사드립니다. 
Jung et al. ; Effect of Natural Water from Deep Sea Rock on the Immune Response and Antioxidant Activity in Rats

\section{VI. 인 용 문 헌}

1. Adams, D. S. and Hamilton, T. A. 1984. The cell biology of macrophage activation. Annu. Rev. Immunol. 2:283-318.

2. Buege, A. J. and Aust, S. D. 1978. Microsomal lipid peroxidation, In Methods in Enzymology, Gleischer, S and Parker, L.(eds), Vol. 52, Academic Press Inc., NY, pp. 302-310.

3. Ding, A. H., Nathan, C. F. and Stuehr, D. J. 1988. Release of reactive nitrogen intermediates from mouse peritoneal macrophages. J. Immunol. 141:2407-2412.

4. Dolgushin, I. I., Kolesnikov, O. L., Selianina, G. A. and Mezentseva, E. A. 2000. An evaluation of the effect of sodium bicarbonate-chloride mineral water on the rat immune system. Vlasov AA. Vopr Kurortol Fizioter Lech Fiz Kult. 4:13-14.

5. Duncan, D. B. 1955. Multiple range and multiple F tests. Biometrics. 11:1.

6. Fusiwara, S., Y. Kato, O., Hirota, T. and Makazato, H. 1990. Immunopotentiating effects of B. longum SBT 2928 showing mitogenic activity in vitro. J. Jpn Soc Nutr. Food Sci. 43:327-333.

7. Halkworth, G., Moseley, L., Carter, K., and Worwood, M. 2003. Iron absorption from Spatone (a natural mineral water) for prevention of iron deficiency in pregnancy, Clin Sab Heamtol. 25(4): 227-231.

8. Hibbs, J. B., Taintor, R. R., Vavrin, I. and Rachlin, W. M. 1988. Nitric oxide: A cytotoxic activated macrophage effector molecule. Biochem. Biophys. Res. commun. 157:87-92.

9. Keller, R., Geiges, M. and Keist, R. 1992. Larginine dependent reactive nitrogen intermediates as mediators of tumor cell killing activated macrophages. Cancer Res. 50:142-1425.

10. Klimetzek, V. and Temold, H. G. 1980. The murine bone marrow macrophage. a sensitive indicator cell for murine migration inhibitory factor and a new method for their harvest. Cell Immunol, 53: 237-266.

11. Kolesnikov, O. L., Selianina, G. A., Dolgushin, I. I. and Kolesnikova, A. A. 2002. The question of mechanisms of the immunotropic effect of mineral drinking waters. Vopr Kurortol Fizioter Lech Fiz Kult. (3):15-17.

12. Kuthan, H., Haussmann, H. J. and Werringloer, J. 1986. A spectrophotometric assay for superoxide dismutase activities in crude tissue fractions. Biochem J. 237(1):175 - 180.

13. Miah, M. R. 1994. Prob, of indus. Wat. Treat. and boil. Wat. Condi. in Bangladesh, Ph.D. Thesis, Dhak. Univ. Dhaka. May.

14. SAS. 1996. SAS user's guide. Release 6.12 edition. SAS Institute. Inc., Cary, NC.

15. Sliverstein, S. and Unkeless, J. 1991. Innate immunity. Curr Opin Immunol. 3:47-57.

16. Steneberg, P., Rubins, N., Bartoov-Shifman, R., Walker, M. D. and Edlund, H. 2005. The FFA receptor GPR40 links hyperinsulinemia, hepatic steatosis, and impaired glucose homeostasis in mouse. Cell Metab. 4:245-58.

17. Thomas, P. M. and Edginton, S. 1984. Hummam monocyte mediated tumor cytotoxictity. J. Immunol. 132:1980-1986.

18. Vladimirov, V. I., Laktionova, A. I. and Polushina, N. D. 2004. Drinking mineral waters in rehabilitation of cancer patients. Vopr Kurortol Fizioter Lech Fiz Kult. 4:16-19.

19. Weir, D. M. 1986. Handbook of experimental immunology. Vol 1 \& 11. 4th ed. Oxford, Blackwell Scientific.

20. Wood, P. D., Haskell, W. L., Blair, S. N., Williams, P. T., Krauss, R. M., Lindgren, F. T., Albers, J. J., Ho, P. H. and Farguhar, J. W. 1983. Increased exercise level and plasma lipoprotein concentrations one-year randomized, controlled study in sedentary middle-aged men. Metabolism, 32:31-39

21. Worwood, M., Evans, W. D., Villis, R. J. and Burnett, A. K. 1996. Iron absorption from a natural mineral water(Spatone Iron Plus). Clin Lab Heamatol. 18:23-27.

22. 丹旸勒負. 2002. 활성산소를 다스리면 무병장수 할 수 있다. 남원우 번역, 문예출판사

23. 최세영, 정영진, 이순재. 2002. 현대인을 위한 식 품과 건강. 동명사.

(접수일자 : 2005. 12. 13. / 채택일자 : 2006. 3. 20.) 